\title{
PILOT-SCALE THERMAL TREATMENT OF AUTOMOTIVE SHREDDER RESIDUE: PYROLYSIS CHAR IS A RESOURCE OR WASTE
}

\author{
ALA KHODIER $^{1}$, KARL S. WILLIAMS ${ }^{1} \&$ NEIL DALLISON ${ }^{2}$ \\ ${ }^{1}$ Centre for Waste Management, School of Forensic and Applied Sciences, \\ University of Central Lancashire, Preston, UK \\ ${ }^{2}$ Recycling Lives Recycling Park, Preston, Lancashire, UK
}

\begin{abstract}
One of the major challenges facing the automotive industry is meeting the recycling and recovery targets set by the revised European End-of-life Vehicles directive (which has set a target of $95 \mathrm{wt} \%$ for recovery from vehicles by 2015). End-of-life vehicles are shredded and the metal content is recovered (typically $75-80 \mathrm{wt} \%$ ). The remaining non-recovered material is $20-25 \mathrm{wt} \%$ (shredder residue). It is this material which must be processed to meet the higher targets. Currently, the residue is disposed of cheaply, which in many cases is landfill. The option to recover material to meet the target is currently limited to mechanical sorting via post-shredder technologies. This is making it difficult to fully implement the requirements of the directive and the future application of the circular economy package. This paper considers the role of advanced thermal processing of shredder residue, which produces gas and oil products that contribute to the EU target. However, to fully meet the targets the authors believe that the char residue is a crucial element. This study presents the results of investigations into the char characteristics from thermal treatment at a pilot-scale rotary kiln at $800-1000^{\circ} \mathrm{C}$. The composition of the char and its calorific value were determined and the critical factors on processing char and its subsequent use are presented. The results of these analyses suggest that thermal treatment may represent a viable process for shredder residue and with the char contribute to meeting the EU targets. The char comprises carbon and hydrocarbons and therefore, any secondary use must be benign within the environment and/or beneficial in secondary waste to energy technology. The paper has demonstrated that subsequent screening of the char and secondary processing will fulfill the EU target.

Keywords: end-of-life vehicles, automotive shredder residue, ASR, char, waste to energy, thermal treatment, pyrolysis, energy recovery.
\end{abstract}

\section{INTRODUCTION}

When a vehicle reaches the end of its life and is classified as an end-of-life vehicle (ELV) it is depolluted, dismantled and shredded in accordance to the ELV Directive. This process yields metals for recycling and currently automotive shredder residue (ASR) for disposal. In some instances, this will undergo post shredder treatment (PST) prior to final disposal [1]. The ASR fraction may represent up to $25 \%$ of ELVs mass and comprises of a complex mixture of organic materials (foams, plastics, rubber, fibres, and textiles) as well as inorganic material (glasses, metals and inserts) [2]. It is anticipated that in the future, as the composition of vehicles changes due to light weighting and new material usage (polymer substitution), the amount of ASR will rise [3], [4]. An additional change to vehicles composition is the increase in electronic components units and the resultant presence of high value resources such as gold and rare earth metals [5], [6]. The characteristics of ASR's calorific value, proximate and ultimate compositions varies depending on the techniques employed in the post shredder treatment at different sites.

The European ELV directive [7] and the new EU circular economy package [8], are forcing the automotive manufacturing industry to rely on the shredding operators meeting the higher recovery target of $95 \%$ [9]. This is also driving the same organisations towards 
zero waste to landfill [8]. In order to meet the higher recovery demand, thermal treatment (such as combustion, gasification and pyrolysis) of the none-recyclable component of ASR has to be considered. Pyrolysis, defined as the thermal degradation of materials in the absence of oxygen, produces the following: (i) condensable organic vapours (that at ambient temperature condense to a liquid); (ii) gases (non-condensable organics) and (iii) a residue carbon a char.

Many researcher [10]-[31], investigating ASR pyrolysis have focused on both the pyrolytic liquids and gases with varying levels of success. These two components are seen to have value as either a raw material or fuel. The char is often considered to have low commercial value. The relative distribution/yield of these products is dependent on the type of feedstock and pyrolysis operating parameters such as: (i) operating temperature, (ii) reactor type, (iii) residence time and (iv) heating rate of the feedstock [32]. Modification of the pyrolysis temperature, will yield the following: (i) predominantly char at low temperature $\left(\leq 450^{\circ} \mathrm{C}\right)$, (ii) liquids/oil at moderate temperature $\left(450-700^{\circ} \mathrm{C}\right)$ and (iii) predominantly gases at high temperature $\left(\geq 800^{\circ} \mathrm{C}\right)$. Char will be produced at the higher pyrolysis temperatures but to a much lesser rate.

Char is composed of carbon with low levels of both nitrogen and hydrogen, which can be considered as a potential fuel. It also contains metals and other inert materials, which may be useful as an inert additive [33]. The carbon content and the compositions of the char can be different as the pyrolysis temperature changes [32], [34].

Harder and Forton, 2007 [35], Vermeulen et al. 2011 [1] and Cossu et al. 2014 [36], in their comprehensive review concluded that the use of ASR pilot-scale pyrolysis experiments were limited. The majority of testing being undertaken at lab-scale (mg-g hr-1). Galvagno et al. 2001 [16], have produced a detailed ASR pilot-scale trial. In order to apply the ASR pyrolysis at an industrial scale, additional research is required at $\mathrm{kg} /$ minute scale plants. At this scale, the practicalities and challenges associated with the processing of the char need to be considered. Ideally, fully commercial plants are required. Currently, there are only three plants or processes that are considered semi or fully commercial proven [36]. These are the Ebara plant (PKA process) in Japan, the Pyromelt process (Lurgi Ensorgung) in Germany and the TWR process (Siemens; Schwel-Brenn; TWR/Mitsui) based in Japan. It should be noted that all three plants are co-processing ASR: for example, the Ebara plant mixes sewage sludge in a 70/30 ratio [37].

In this work, ASR was pyrolysed in a pilot-scale rotary kiln test rig at $10 \mathrm{~kg} \mathrm{hr}^{-1}$. The resulting by-product char from the pyrolysis operating continuously at a different temperatures were investigated.

\section{MATERIALS AND METHOD}

\subsection{ASR material}

The ASR was obtained from a shredder plant in the Northwest of the UK. Full description of the plant, ASR downstream separation, ASR sizes and the amount of ASR production can be seen in Khodier et al. 2017 [38]. The ASR used in the study comprised of plastics, rubber, foam, textile, cork and wood (see Fig. 1(a)). The ASR compositions are given in Table 1. The $150 \mathrm{~mm}$ size fraction of ASR produced by the plant was subsequently, crushed through a $15 \mathrm{~mm}$ screen using a UNTHA UK Type RS40-1000 shredder. This ensured a homogeneous feed into the pyrolysis plant as shown in Fig. 1(b). 


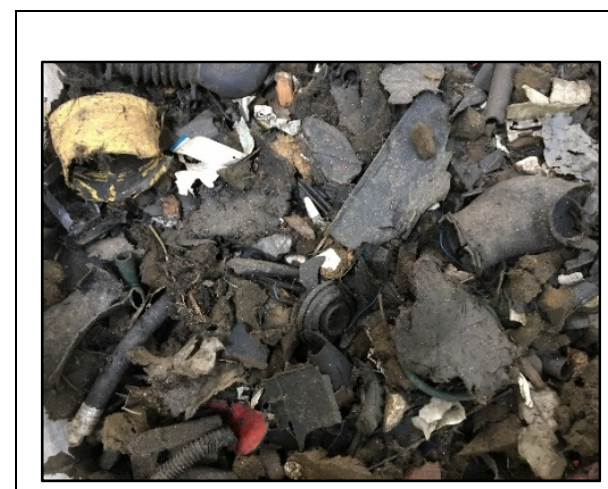

(a)

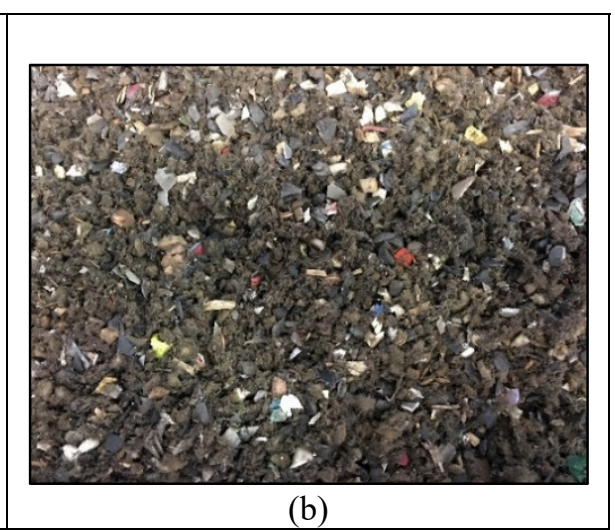

(b)

Figure 1: Trial ASR material. (a) As received: $\leq 150 \mathrm{~mm}$; (b) Crushed and screened $\leq 15 \mathrm{~mm}$.

Table 1: Proximate, ultimate analysis, calorific value and materials constituents of the ASR used in the study [38].

\begin{tabular}{|c|c|c|c|c|c|c|}
\hline \multirow[t]{2}{*}{ Parameter $^{\mathrm{a}}$} & \multirow[t]{2}{*}{ Units } & \multirow[t]{2}{*}{ Results } & & \multicolumn{3}{|c|}{ Components } \\
\hline & & & & $\mathrm{mg} / \mathrm{kg}$ & & $\mathrm{wt} \%$ \\
\hline Gross Calorific value & $\mathrm{kJ} / \mathrm{kg}$ & $16300-32500$ & Metals & & Plastic & 47.88 \\
\hline Proximate analysis & & & Copper & 7 & Foam & 2.94 \\
\hline Moisture & $\mathrm{wt} \%$ & 22 & Mercury & $<1$ & Rubber & 15.88 \\
\hline Ash & $\mathrm{wt} \%$ & 20 & Cadmium & $<1$ & Textile/fabric & 10.35 \\
\hline Volatile matter & $\mathrm{wt} \%$ & 53 & Thallium & $<1$ & Cork & 11.05 \\
\hline Fixed carbon & $\mathrm{wt} \%$ & 5 & Antimony & 12 & Wood & 1.17 \\
\hline Total & $w t \%$ & 100 & Arsenic & $<1$ & Wiring/electrical & 1.76 \\
\hline Ultimate analysis & & & Chromium & 16 & Glass & 0.82 \\
\hline Carbon & $\mathrm{wt} \%$ & 28 & Cobalt & $<1$ & Paper & 0.47 \\
\hline Hydrogen & $w t \%$ & 3 & Lead & 56 & Cardboard & 0.23 \\
\hline Nitrogen & $\mathrm{wt} \%$ & 2 & Manganes & 24 & Dirt & 0.35 \\
\hline Oxygen & $\mathrm{wt} \%$ & 14 & $\mathrm{e}$ & 7 & Fines (e.g. soil) & 6.57 \\
\hline Sulphur & $w t \%$ & 0.2 & Nickel & $<1$ & Metals ${ }^{\mathrm{b}}$ & 0.47 \\
\hline Chlorine & $w t \%$ & 0.3 & $\begin{array}{l}\text { Tin } \\
\text { Vanadium }\end{array}$ & $<1$ & Others & 0.06 \\
\hline
\end{tabular}

${ }^{a}$ ASR $=$ as-received (AR) after shredding.

${ }^{\mathrm{b}}$ fine metals caught into a soil/dirt, hard to separate.

\subsection{Rotary Pilot test plant}

Fig. 2 shows the pilot-scale rotary kiln, used for this study. The kiln comprised a stainlesssteel kiln, which was $3.5 \mathrm{~m}$ long with an internal diameter $0.38 \mathrm{~m}$. This was surrounded by an externally heated gas fired furnace up to $1100^{\circ} \mathrm{C}$ in four independent zones (total length 2 $\mathrm{m}$ ) each with PID control. The feed hopper had a screw delivery capacity up to $100 \mathrm{~kg} \mathrm{hr}^{-1}$ via an airtight closure system and rotation speed controller (inverter). The furnace temperatures were measured along the length via sensors connected to a data logger (Pico logger unit). The kiln rotation speed had a range of 1 to $12 \mathrm{rpm}$ (to allow variable residence times in the hot zone), with slop angle up to $10^{\circ}$. The system allowed the continuous char 
discharged from end of the rotary kiln into a sealed drum collecting the heaviest char (coarse) and the fine char collected at a subsequent point.

In the pyrolysis tests, air inside the plant was removed by purging with nitrogen (flow rate of $101 \mathrm{~min}^{-1}$ ) which was injected below the feeding hopper. The rotation speed of the kiln was set at $2 \mathrm{rpm}$ and the kiln slope angle of $1^{\circ}$. The kiln was heated at $5^{\circ} \mathrm{C} \mathrm{min}{ }^{-1}$ up to the test pyrolysis temperature of (i) $800^{\circ} \mathrm{C}$, (ii) $900^{\circ} \mathrm{C}$ and (iii) $1000^{\circ} \mathrm{C}$. The feeding of ASR started when kiln reached the pyrolysis temperature set point (e.g. $\left.800^{\circ} \mathrm{C}\right)$. Initial feeding rate of 10 $\mathrm{kg} \mathrm{hr}^{-1}$ (inverter was set at power of 15\%) was used. Each trial was run for 3 hours under these set conditions. Char was collected after each test, weighed and stored for chemical and physical analysis.

\subsection{Char analysis}

The gross calorific value (CV) was measured using a Parr 6200 Isoperibol bomb calorimeter (Scientific \& Medical Production Ltd, UK) followed BS EN 15400:2011 [39], protocol. Char proximate analysis of the moisture, ash and volatile matter were determined according to British Standard methodologies of BS EN 15414:2011 [40], BS EN 15403:2011 [41], BS EN 15402:2011 [42], respectively. Fixed carbon was calculated to give a total of 100 ( $\%$ by, weight) of the proximate analysis.

Ultimate analysis of the char were carried out using CHNS-O Flash 2000 Organic Elemental Analyser (Thermo Scientific). BBOT (2,5-Bis(5-tert-butyl-2-benzo-oxalzol-2-yl) thiophene, $\left.\left(\mathrm{C}_{26} \mathrm{H}_{26} \mathrm{~N}_{2} \mathrm{O}_{2} \mathrm{~S}\right)\right)$ standard was used. The mass samples of the char were approximate $2-3 \mathrm{mg}$ combusted at temperature of $850^{\circ} \mathrm{C}$.

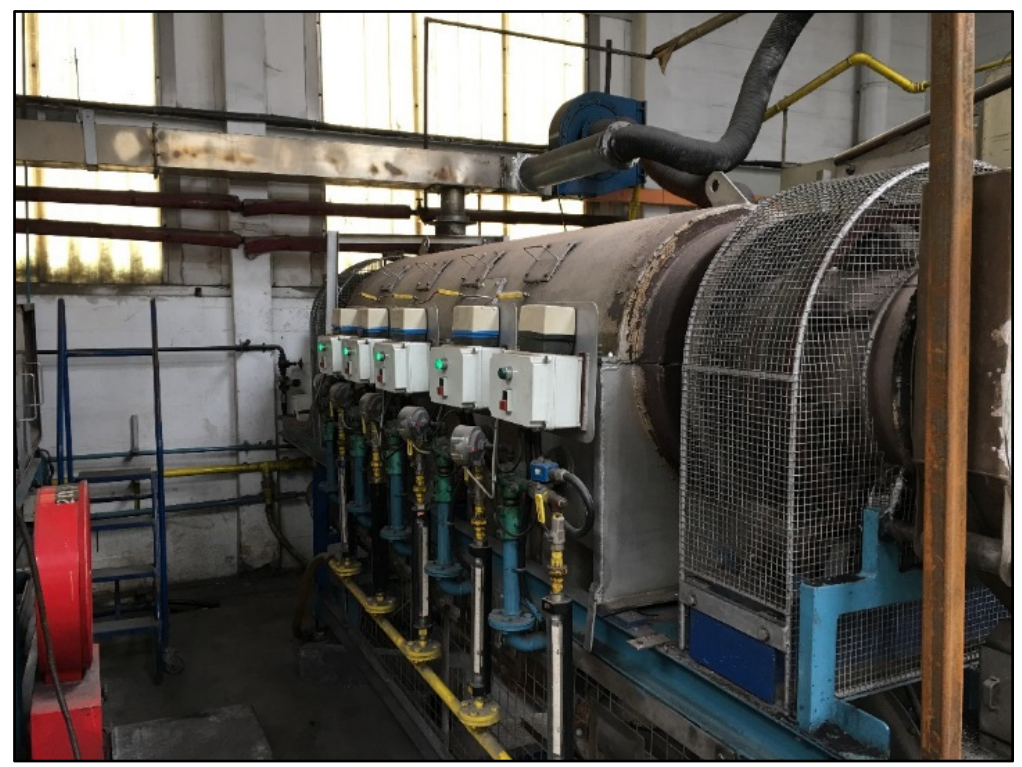

Figure 2: Pilot-scale rotary kiln test plant (based at Mitchell Dryers - CAD Works Engineering Ltd, Carlisle, UK). 
Inductively coupled plasma mass spectrometry (ICP-MS) was used to measure the metals. Open survey resulted a list of measured metals of Be, $\mathrm{Na}, \mathrm{Mg}, \mathrm{Al}, \mathrm{K}, \mathrm{Ti}, \mathrm{Cu}, \mathrm{Mn}, \mathrm{V}, \mathrm{Zn}, \mathrm{Mo}$, $\mathrm{Cr}, \mathrm{Ni}, \mathrm{Ca}, \mathrm{Fe}, \mathrm{As}, \mathrm{Se}, \mathrm{Ba}, \mathrm{Pb}, \mathrm{Hg}, \mathrm{Ag}, \mathrm{Sb}, \mathrm{Cd}, \mathrm{Tl}, \mathrm{Li}, \mathrm{Au}$. The samples of about $0.1 \mathrm{~g}$ were dissolved in $\mathrm{HNO}_{3}$ and subjected to microwave digestion (programmed for $0-200^{\circ} \mathrm{C}$ (in 10 $\mathrm{min}$ ), held for $15 \mathrm{~min}$ and cooled down over a period of $35 \mathrm{~min}$ ) prior ICP-MS analysis.

Morphological analysis of the char was carried out using Scanning Electron Microscope (SEM) equipped with X-ray Diffraction (XRD) analyses. The samples were prepared on the front face of $12.5 \mathrm{~mm}$ diameter, $6 \mathrm{~mm}$ pin length specimen stub. The stub samples were gold coated using Emitech K550X sputter coater and later placed into specific sample holder for examination. In EDX, elemental quant feature was used for $\mathrm{C}, \mathrm{N}, \mathrm{O}, \mathrm{Na}, \mathrm{Mg}, \mathrm{Al}, \mathrm{Si}, \mathrm{P}, \mathrm{S}, \mathrm{Cl}$, $\mathrm{Ar}, \mathrm{Ag}, \mathrm{Cd}, \mathrm{K}, \mathrm{Ca}, \mathrm{Ba}, \mathrm{Ti}, \mathrm{V}, \mathrm{Cr}, \mathrm{Mn}, \mathrm{Fe}, \mathrm{Co}, \mathrm{Ni}, \mathrm{Cu}, \mathrm{Zn}, \mathrm{Au}, \mathrm{Hg}, \mathrm{Tl}, \mathrm{As}, \mathrm{Pb}$ and Br. In SEM, higher images magnifications scanning at $40 \mathrm{x}$ were preferred.

\section{RESULTS AND DISCUSSION}

Fig. 3 shows an example the profile of initial heating and test temperature inside the kiln (test (iii) $1000^{\circ} \mathrm{C}$ ) indicating two and half-hours of stable ASR pyrolysis. At the end of the test the furnace was turned off.

The calorific value, proximate analysis and the metals content of the product pyrolysis char (fine and coarse) are presented in Table 2. The volatile matter content of the ASR char in fine formation decreases as the temperature of the pyrolysis increases. Whereas, the fixed carbon contents of the char correlated with the temperature, similar to other reported studies [16], [27], [31]. The ash contents also correlated with the pyrolysis temperature. However, ash contents in the pyrolysis char-fine were very low compared to char-coarse at all pyrolysis temperature studied. The calorific value of the char-fine formation at $800^{\circ} \mathrm{C}, 900^{\circ} \mathrm{C}$ and $1000^{\circ} \mathrm{C}$ range from $17.0-27.7 \mathrm{MJ} / \mathrm{kg}, 16.3-26.3 \mathrm{MJ} / \mathrm{kg}$ and $15.6-23.8 \mathrm{MJ} / \mathrm{kg}$, respectively.

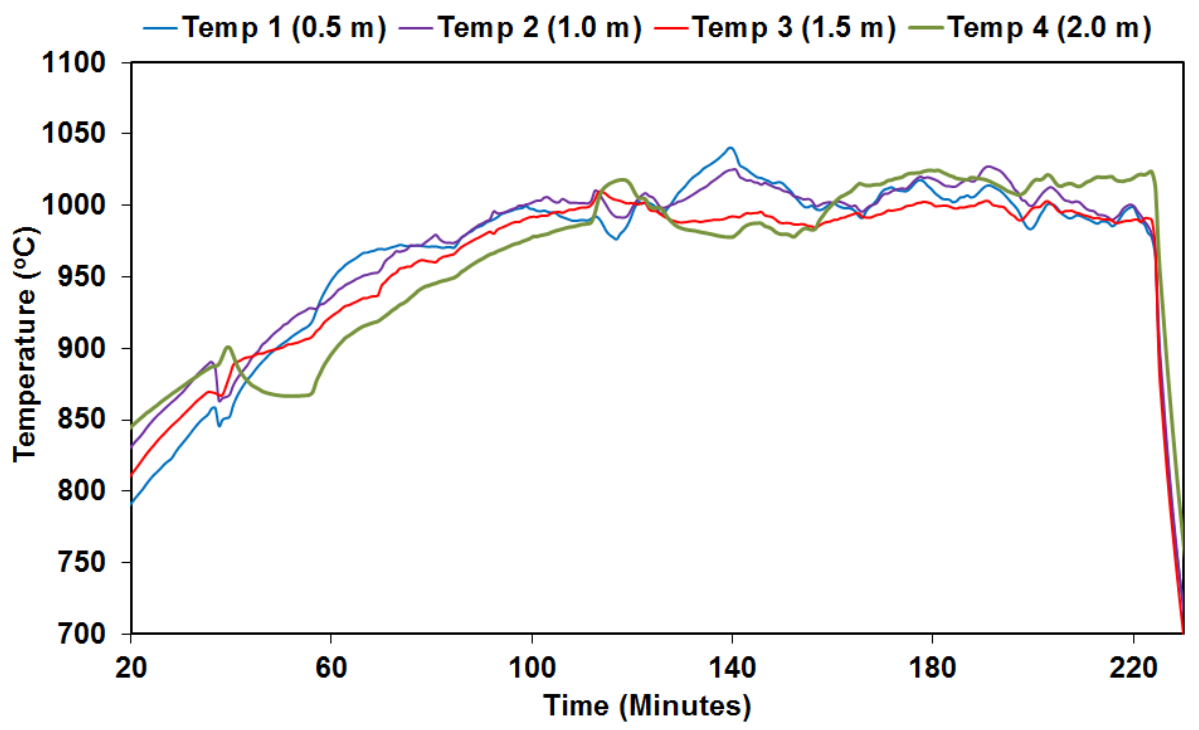

Figure 3: Profile of steady state temperature at the pilot-scale rotary kiln during ASR pyrolysis (includes initial heating process). Heated zone represent distance from feed in heated zone. 


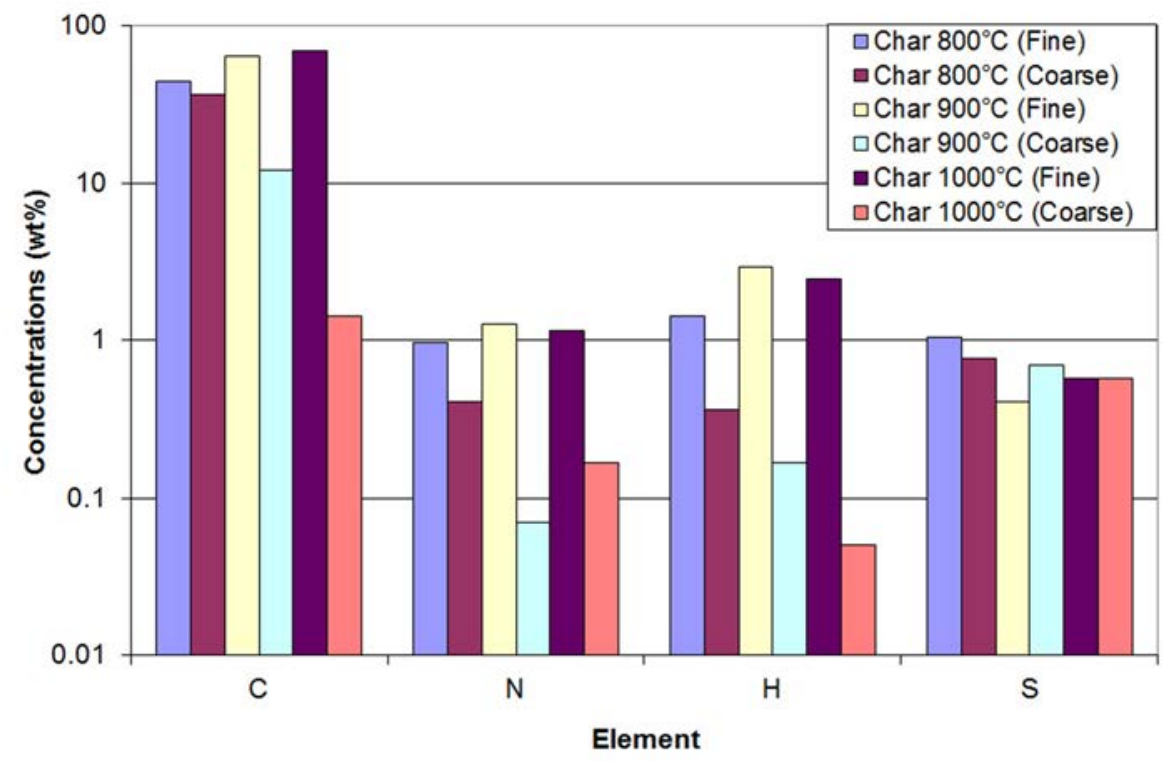

Figure 4: Organic elemental analysis of the ASR pyrolysis char generated at various temperatures in fine and coarse formation.

Zolezzi et al. 2004 [21] reported that the same relationship between lower calorific value of the char and the pyrolysis process temperature. The calorific value of the ASR pyrolysis char in the coarse forms only perceived at char coarse $800^{\circ} \mathrm{C}$. Galvagno et al. 2001 [16] explained that the calorific values are influenced by the content of the hydrogen in the char. Fig. 4 presents the $\mathrm{C}, \mathrm{H}, \mathrm{N}$ and $\mathrm{S}$ organic elements of the chars (fine and coarse) produced from the pyrolysis process. It is clear that the hydrogen contents in the char-coarse at $800^{\circ} \mathrm{C}$ are higher compared to char-coarse at $900^{\circ} \mathrm{C}$ and $1000^{\circ} \mathrm{C}$. In contrast with nitrogen content which had higher concentrations in the char-fine fractions. The sulphur contents in all char samples were minimal with highest value of $1.05 \%$ reported at char $800^{\circ} \mathrm{C}$-fine. This is related to the low content of the sulphur $(0.2 \%)$ in the raw ASR feedstock (as shown in Table 1).

The most abundant metals of the pyrolysis chars (as shown in Table 2) were calcium, manganese, aluminium, chromium, lead, iron, nickel and zinc. The element contents of iron, calcium, nickel, aluminium and copper were higher in the char-coarse compared to the char in the fine formation. It was noted that the copper was low in all char products in contrast to other reported studies such as Day et al. 1996 [12] and Notarnicola et al. 2017 [31]. This was mainly due to the copper contents in their original ASR (feedstock) are much higher compared to the raw ASR feedstock used in this study.

It can be seen from Fig. 5(c) and 5(e) that the char-fine produced at the highest temperatures $900^{\circ} \mathrm{C}$ and $1000^{\circ} \mathrm{C}$ has smaller pores than char-fine at $800^{\circ} \mathrm{C}$. At the lower temperature, the molecules which volatilise have higher molecular weight and will create larger holes on the char surface [31]. The images of char-coarse resulted a silicate type of structure in particular char-coarse at $1000^{\circ} \mathrm{C}$ (Fig. 5(f)) due to the mixed materials of fines presented. 
Table 2: Ultimate analysis, calorific value and metals contents of the char products (fine and coarse) at various temperatures.

\begin{tabular}{|c|c|c|c|c|c|c|}
\hline \multirow[t]{3}{*}{ Parameter } & \multicolumn{6}{|c|}{ Pyrolysis char } \\
\hline & $800^{\circ} \mathrm{C}$ & $800^{\circ} \mathrm{C}$ & $900^{\circ} \mathrm{C}$ & $900^{\circ} \mathrm{C}$ & $1000^{\circ} \mathrm{C}$ & $1000^{\circ} \mathrm{C}$ \\
\hline & -Fine- & -Coarse- & -Fine- & -Coarse- & -Fine- & -Coarse- \\
\hline $\mathrm{HHV}(\mathrm{kJ} / \mathrm{kg})$ & $\begin{array}{l}17063- \\
27741\end{array}$ & $\begin{array}{l}2378- \\
4189\end{array}$ & $\begin{array}{l}16317- \\
26309\end{array}$ & $\begin{array}{l}\text { Not- } \\
\text { detected }\end{array}$ & $\begin{array}{l}15681- \\
23895\end{array}$ & $\begin{array}{l}\text { Not- } \\
\text { detected }\end{array}$ \\
\hline Moisture (wt $\%)$ & 0.48 & 0.02 & 0.23 & 0.04 & 0.47 & 0.01 \\
\hline Ash (wt\%) & 31.65 & 75.40 & 17.03 & 82.41 & 10.76 & 92.89 \\
\hline VM (wt\%) & 45.43 & 19.14 & 27.02 & 17.52 & 23.01 & 6.30 \\
\hline Fixed Carbon (wt $\%$ ) & 22.44 & 5.44 & 55.72 & 0.03 & 65.76 & 0.80 \\
\hline \multicolumn{7}{|l|}{ Metals (mg/kg) } \\
\hline $\mathrm{Ca}$ & 23120.8 & 47282.1 & 14613.9 & 54340.6 & 21224.0 & 57274.5 \\
\hline Co & 37.5 & 72.5 & 5.8 & 113.0 & 8.6 & 100.4 \\
\hline $\mathrm{Al}$ & 5400.5 & 228617.1 & 1355.6 & 1116575 & 1886.4 & 143409.3 \\
\hline $\mathrm{Cr}$ & 2343.4 & 2857.7 & 65.9 & 27390.1 & 161.9 & 12715.5 \\
\hline $\mathrm{Mg}$ & 18772.5 & 30527.5 & 3238.9 & 19560.4 & 3723.5 & 23746.2 \\
\hline $\mathrm{Fe}$ & 930.9 & 38393.2 & 1848.3 & 48241.7 & 2639.6 & 50475.7 \\
\hline $\mathrm{Ni}$ & 201.7 & 3800.9 & 163.6 & 64139.1 & 470.5 & 14013.8 \\
\hline $\mathrm{Cu}$ & 600.5 & 28864.9 & 709.4 & 15018.3 & 877.8 & 19444.9 \\
\hline $\mathrm{Zn}$ & 5617.5 & 2865.7 & 11139.7 & 9542.1 & 8693.9 & 6296.3 \\
\hline $\mathrm{Pb}$ & 670.3 & 297.2 & 2242.6 & 481.5 & 1832.1 & 349.7 \\
\hline $\mathrm{V}$ & 16.5 & 52.3 & 2.7 & 66.1 & 4.4 & 44.9 \\
\hline
\end{tabular}

Fig. 6 shows the EDX elemental compositions of the char products formed in both fine and coarse fractions. The figure reveals varying concentrations of carbon, nitrogen, oxygen, aluminium, silicon, calcium, sulphur, potassium, zinc, cooper, iron, lead and bromine among char-fine and char-coarse. The lowest percentage of $\mathrm{O}_{2}$ resulted at char-fine $1000^{\circ} \mathrm{C}$ of $2.91 \%$, in agreement with other study [27] reported the effect of the pyrolysis temperature on the oxygen content of the char. The levels of chlorine in the chars were very low due to low contents of $\mathrm{Cl}$ presented in the raw ASR feedstock (Table 1). The commercially produced raw ASR was subjected to mechanical post-shredder technologies, which removed the electric cables [38]. The elemental analysis results by EDX confirmed the other metals analysis procedure used in this study. For example, the carbon concentration of the char-fine at $800^{\circ} \mathrm{C}$, char-fine $900^{\circ} \mathrm{C}$ and char-fine $1000^{\circ} \mathrm{C}$ by EXD analysis were $45.93 \mathrm{wt} \%, 50.56$ $\mathrm{wt} \%$ and $56.25 \mathrm{wt} \%$, respectively. This correlation mirrored the results found in the carbon concentrations of char-fine at $800^{\circ} \mathrm{C}$, char-fine $900^{\circ} \mathrm{C}$ and char-fine $1000^{\circ} \mathrm{C}$ by CHNS-O organic analyser (Fig. 4) of $44.87 \mathrm{wt} \%, 64.82 \mathrm{wt} \%$ and $69.18 \%$, respectively. The higher concentrations of iron found by ICP-MS in char-coarse for all the test temperatures studied: this was similar the results recorded by EDX.

It is clear that the char-products from a pilot-scale rotary kiln pyrolysis process could be considered as a resources. Therefore, they would contribute to the ELV recovery target and no longer be landfilled. The unique design of this kiln pyrolysis trials resulting in two distinct a char product (fine and coarse (heaviest)) would enable commercialisation of the char products. This will ensure the optimisation of the higher calorific value char and may avoid further char upgrading process. Improvement of this work could be the assessment of organic pollutants such as PAHs in the char-products obtained at various temperatures. Other studies could investigate metal recovery from the different chars. 


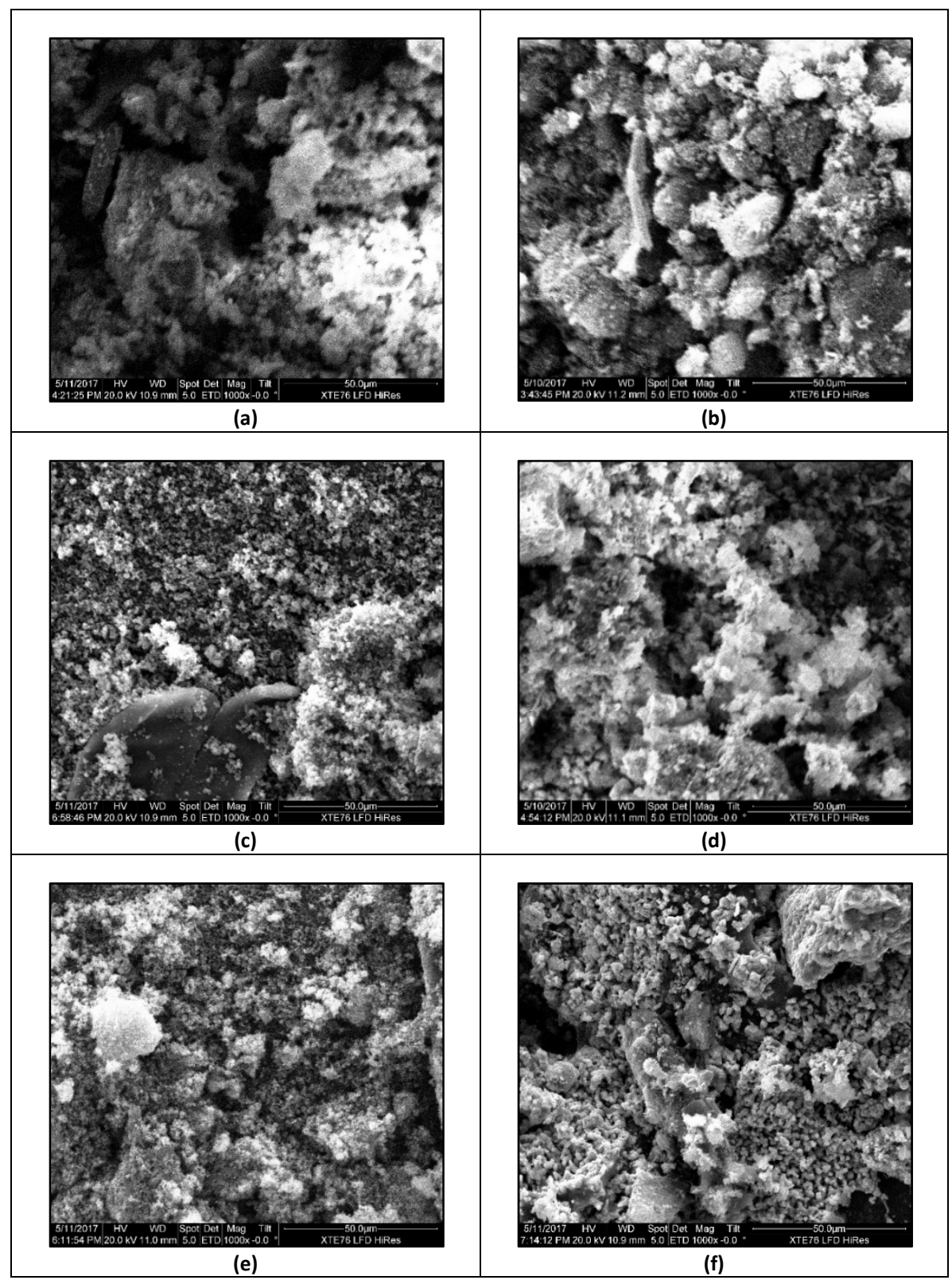

Figure 5: SEM images of the ASR pyrolysis char generated from pilot-scale kiln. (a) Fine char at $800^{\circ} \mathrm{C}$; (b) Coarse char at $800^{\circ} \mathrm{C}$; (c) Fine char at $900^{\circ} \mathrm{C}$; (d) Coarse char at $900^{\circ} \mathrm{C}$; (e) Fine char at $1000^{\circ} \mathrm{C}$; (f) Coarse char at $1000^{\circ} \mathrm{C}$. 


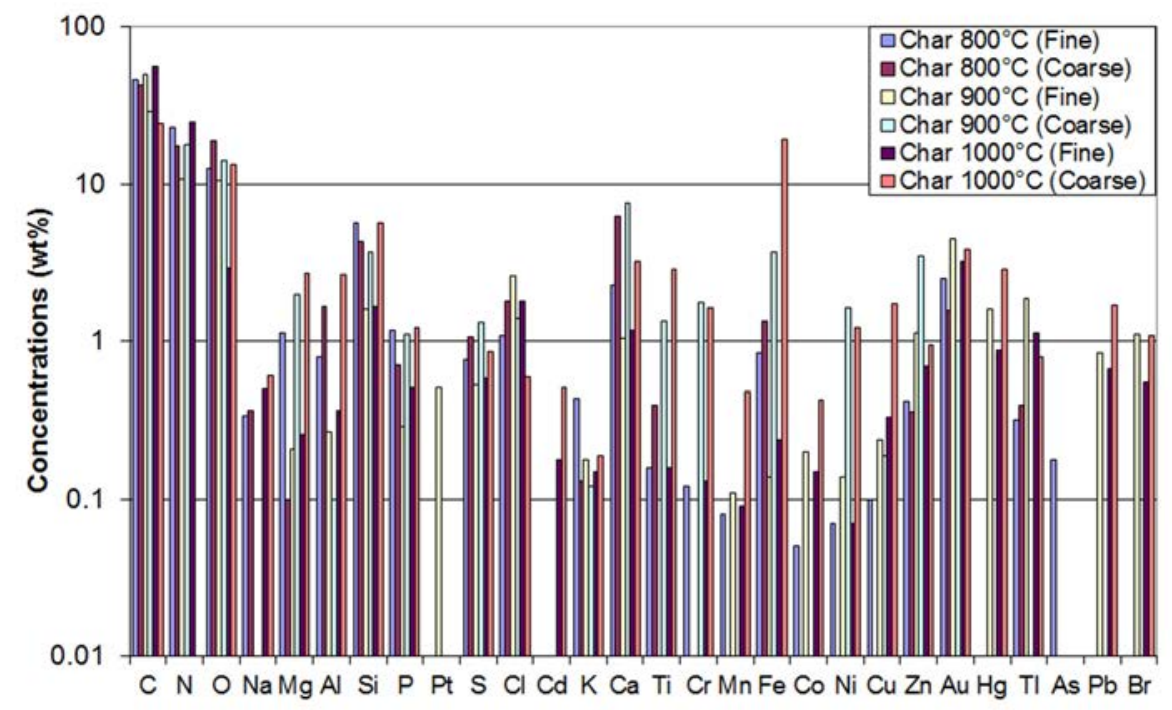

Element

Figure 6: EDX analysis of the ASR pyrolysis char generated at various temperatures in fine and coarse formation.

\section{CONCLUSIONS}

Automotive shredder residue from a commercial plant (ASR) was pyrolysed in a pilot-scale rotary kiln rig to optimise products. The test explored the potential of a pyrolysis process with the additionality of the recovery of useful char by-products. This would be an alternative to landfilling. This would assist in meeting the new ELV Directive targets and the future application of the circular economy package. A series of pyrolysis tests at different temperatures of $800^{\circ} \mathrm{C}, 900^{\circ} \mathrm{C}$ and $1000^{\circ} \mathrm{C}$ have been investigated. The main conclusions can be summarised as follows:

- The pyrolysis rotary kiln system performed well with ASR ( $\leq 20 \mathrm{~mm}$ size fraction), producing stable pyrolysis of the materials.

- The calorific value of the by-product chars (in fine fraction) was high in every pyrolysis temperature and it is maximal at $800^{\circ} \mathrm{C}$.

- Char-coarse calorific value is notably low, therefore it is not viable for energy recovery. However, it may still benefit as a filler in construction material or a secondary source for metals.

- Ash contents in the char-coarse have to be considered.

- Highest carbon contents and lowest oxygen contents recorded for char-fine produced at $1000^{\circ} \mathrm{C}$.

- The char abundant metal were comparable at all pyrolysis temperatures except Fe, $\mathrm{Ca}, \mathrm{Ni}, \mathrm{Al}$ and $\mathrm{Cu}$ were higher in the chars-coarse.

- Low levels of copper and chlorine were found in the char revealed the important of pre-treatment of ASR before thermal treatment. 
- $\quad$ SEM images highlighted that the char structure at higher pyrolysis temperatures is more microporous.

- The segregation of char would assist in optimisation of energy and resource recovery.

\section{ACKNOWLEDGEMENTS}

The authors gratefully acknowledge Innovate UK's financial support through the Knowledge Transfer Partnership (KTP) and Recycling Lives Limited, Preston, UK for their financial support and access to their facility.

\section{REFERENCES}

[1] Vermeulen, I., Van Canegham, J., Block, C., Baeyens, J. \& Vandecasteele, C., Automotive shredder residue (ASR): reviewing its production from end-of-live vehicles (ELVs) and its recycling, energy or chemical valorisation. Journal of Hazardous Materials, 190(1), pp. 8-27, 2011.

[2] Cossu, R. \& Lai, T., Automotive shredded residue (ASR) management: an overview. Waste Management, 45, pp. 143-151, 2015.

[3] Davies, G., (2 eds), Materials for Automobile Bodies, Elsevier Applied Science Publisher: Amsterdam, pp. 11-13, 2012.

[4] Alonso, J.C., Doce, J., Fleischer, G., Geraghty, K., Greif, A., Rodrigo, J. \& Schmidt, W.P., Electrical and electronic components in the automotive sector: economic and environment. International Journal of Life Cycle Assessment, 12(5), pp. 328-335, 2007.

[5] Cucchiella, F., D’Adamo, I., Rosa, P. \& Terzi, S., Automotive printed circuit boards recycling: An economic analysis. Journal of Cleaner Production, 121, pp. 130-141, 2016.

[6] Restrepo, E., Løvik, A.N., Wäger, P., Widmer, R., Lonka, R. \& Müller, D.B., Stocks, flows and distribution of critical metals in embedded electronics in passenger vehicles. Environmental Science \& Technology, 51(3), pp. 1129-1139, 2017.

[7] EC, 2000 Directive 2000/53/EC of the European Parliament and the European Council of 18 September 2000 on End-of-Life Vehicles - Commission Statements. Off. J. Eur. Comm. L269, 0034-0043, Brussels.

[8] European Parliamentary Research Service, Closing the Loop: New Circular Economy Package,www.europarl.europa.eu/RegData/etudes/BRIE/2016/573899/EPRS_BRI(2 016)573899_EN.pdf. Accessed on: 5 Jun. 2017.

[9] Ruffino, B., Fiore, S. \& Zanetti, M.C., Strategies for the enhancement of automobile shredder residues (ASRs) recycling: results and cost assessment. Waste Management, 34(1), pp. 148-155, 2014.

[10] Braslaw, J., Melotik, D.J., Gealer, R.L. \& Wingfield, R.C. Jr, Hydrocarbon generation during the inert gas pyrolysis of automobile shredder waste. Themochimica Acta, 196, pp. 1-18, 1991.

[11] Shen, Z., Day, M., Cooney, J.D., Lu, G., Briens, C.L. \& Bergrougnou, M.A., Ultrapyrolysis of automobile shredder residue. The Canadian Journal of Chemical Engineering, 73, pp. 357-366, 1995.

[12] Day, M., Cooney, J.D. \& Shen, Z., Pyrolysis of automobile shredder residue: an analysis of the products of a commercial screw kiln process. Journal of Analytical and Applied Pyrolysis, 37, pp. 49-67, 1996. 
[13] Rausa, R. \& Pollesel, P., Pyrolysis of automobile shredder residue (ASR) - influence of temperature on the distribution of products. Journal of Analytical and Applied Pyrolysis, 40-41, pp. 383-401, 1997.

[14] Chaala, A., Ciochina, O.G. \& Roy, C., Vacuum pyrolysis of automobile shredder residue: use of the pyrolytic oil as a modifier for road bitumen. Resources, Conservation and Recycling, 261, pp. 155-172, 1999.

[15] Day, M., Shen, Z. \& Cooney, J.D., Pyrolysis of auto shredder residues: experiments with a laboratory screw kiln reactor. Journal of Analytical and Applied Pyrolysis, 51, pp. 181-200, 1999.

[16] Galvagno, S., Fortuna, F., Cornacchia, G., Casu, S., Coppola, T. \& Sharma, V.K., Pyrolysis process for treatment of automobile shredder residue: preliminary experimental results. Energy Conversion and Management, 42, pp. 573-586, 2001.

[17] Roy, C. \& Chaala, A., Vacuum pyrolysis of automobile shredder residue. Resources, Conservation and Recycling, 32(1), pp. 1-27, 2001.

[18] De Marco, I., Caballero, B.M., Torres, A., Laresgoiti, M.F., Chomón, M.J. \& Cabero, M.A., Recycling polymeric wastes by means of pyrolysis. Journal of Chemical Technology and Biotechnology, 77, pp. 817-824, 2002.

[19] Chiarioni, A., Reverberi, A.P., El-Shaarawi, A.P. \& Dovì, V.G., Modelling of an ASR countercurrent pyrolysis with nonlinear kinetics. Applied Thermal Engineering, 23(14), pp. 1847-1855, 2003.

[20] Pasel, C. \& Wanzi, W., Experimental investigations on reactor scale-up and optimisation of product quality in pyrolysis of shredder waste. Fuel Processing Technology, 88(1), pp. 47-67, 2003.

[21] Zolezzi, M., Nicolella, C., Ferrara, S., Iacobucci, C. \& Rovatti, M., Conventional and fast pyrolysis of automobile shredder residue (ASR). Waste Management, 24, pp. 691699, 2004.

[22] De Marco, I., Caballero, B.M., Cabero, M.A., Laresgoiti, M.F., Torres, A. \& Chomón, M.J., Recycling of automobile shredder residues by means of pyrolysis. Journal of Analytical and Applied Pyrolysis, 79, pp. 403-408, 2007.

[23] Joung, H.T., Seo, Y.C., Kim, K.H., Hong, J.H. \& Yoo, T.W., Distribution and characteristics of pyrolysis products from automobile shredder residue using an experimental semi-batch reactor. Korean Journal of Chemical Engineering, 24(6), pp. 996-1002, 2007.

[24] Donaj, P., Yang, W., Blasiak, W. \& Forsgren, C., Recycling of automobile shredder residue with a microwave pyrolysis combined with high temperature steam gasification. Journal of Hazardous Materials, 182(1), pp. 80-89, 2010.

[25] Santini, A., Passarini, F., Vassura, I., Serrano, D., Dufour, J. \& Morselli, L., Auto shredder residue recycling: mechanical separation and pyrolysis. Waste Management, 32, pp. 852-858, 2012.

[26] Roh, S.A., S.A., Kim, W.H., Yun, J.H., Min, T.J., Kwak, Y.H. \& Seo, Y.C., Pyrolysis and gasification-melting of automobile shredder residue. Journal of the Air and Waste Management Association, 63(10), pp. 1137-1147, 2013.

[27] Haydary, J., Susa, D., Gelinger, V. \& Cacho, F., Pyrolysis of automobile shredder residue in a laboratory scale screw type reactor. Journal of Environmental Chemical Engineering, 4, pp. 995-972, 2016.

[28] Mayyas, M., Pahlevani, F., Handoko, W. \& Sahajwalla, V., Preliminary investigation on the thermal conversion of automotive shredder residue into value-added products: graphitic carbon and nano-ceramics. Waste Management, 50, pp. 173-183, $2016 \mathrm{a}$. 
[29] Mayyas, M., Mayyas, M., Pahlevani, F., Liuc, Z., Rajaraoa, R. \& Sahajwalla, V., From automotive shredder residue to nano-ceramics and graphitic carbon-Thermal degradation kinetics. Journal of Analytical and Applied Pyrolysis, 120, pp. 60-74, 2016b.

[30] Rey, L., Conesa, J.A., Aracil, I., Garrido, M.A. \& Ortuño, N., Pollutant formation in the pyrolysis and combustion of automotive shredder residue. Waste Management, 56, pp. 376-383, 2016.

[31] Notarnicola, M., Cornacchia, G., De Gisi, S., Di Canio, F., Freda, C., Garzone, P., Martino, M., Valerio, V. \& Villone, A., Pyrolysis of automotive shredder residue in a bench scale rotary kiln. Waste Management, In Press, corrected proof. Available on: 11 Apr. 2017.

[32] Williams, P.T., (2 eds), Waste Treatment and Disposal, John Wiley \& Sons Ltd: Chichester, pp. 326-336, 2005.

[33] Fortuna F., Cornacchia, G., Mincarini, M. \& Sharma, V.K., Pilot-scale experimental pyrolysis plant: mechanical and operational aspects. Journal of Analytical and Applied Pyrolysis, 40-41, pp. 403-417, 1997.

[34] Tchobanoglous, G., Theisen, H. \& Vigil, S., Integrated Solid Waste Management, McGraw Hill: London, pp. 978, 1993.

[35] Harder, M.K. \& Forton, O.T., A critical review of development in the pyrolysis of automotive shredder residue. Journal of Analytical and Applied Pyrolysis, 79(1-2), pp. 387-394, 2007.

[36] Cossu, R., Fiore, S., Lai, T., Luciano, A., Mancini, G., Ruffino, B., Viotti, P. \& Zanetti, M.C., Review of Italian experience on automotive shredder residue characterisation and management. Waste Management, 34, pp. 1752-1762, 2014.

[37] Selinger, A., Steiner, C. \& Shin, K., TwinRec - bridging the gap of car recycling in Europe. Proceedings of the International Automotive Recycling Congress, Geneva, Switzerland, March 12-14, 2003.

[38] Khodier, A., Williams, K. \& Dallison, N., Challenges around automotive shredder production and disposal. Waste Management, In Press, corrected proof. Available on: 10 May 2017.

[39] BS, British Standards, BS EN 15400: Solid Recovered Fuels - Determination of Calorific Value, British Standard Institute, 2011.

[40] BS, British Standards, BS EN 15414: Solid Recovered Fuels - Determination of Moisture Content Using the Oven Dry Method - Part 3: Moisture in General Analysis Sample, British Standard Institute, 2011.

[41] BS, British Standards, BS EN 15403: Solid Recovered Fuels - Determination of Ash Content, British Standard Institute, 2011.

[42] BS, British Standards, BS EN 15402: Solid Recovered Fuels - Determination of the Content of Volatile Matter, British Standard Institute, 2011. 